\title{
Lifetime Earnings, Mortality, And Social Security Benefits: Implications For Reform
}

Alan D. Eastman, Indiana University of Pennsylvania, USA Kevin L. Eastman, Georgia Southern University, USA

\begin{abstract}
The Social Security system is facing significant financial challenges, but politicians, economists, and other experts cannot agree on appropriate solutions. Raising taxes and/or cutting benefits are never popular proposals, and competing groups want to protect the poor while at the same time maintain fairness for the more wealthy. Recent studies, such as Cristia (2007), Duggan et al. (2007), and Waldron (2007), have shown a strong correlation between lifetime earnings and mortality, suggesting that differences in life expectancy between the wealthy and the less wealthy may be getting larger, thus eroding the progressivity of the Social Security system. Our results show that for a mortality difference of one or two years, benefit reductions in the range of $2.5 \%$ to $16 \%$ would be needed to maintain the current level of progressivity for a male living to age 80 . If the mortality difference grows to four or five years, the benefit reductions would need to be much greater, anywhere from approximately $14 \%$ to $31 \%$. A reduction in benefits based on lifetime earnings can improve the long-run viability of the Social Security system while maintaining its current level of progressivity.
\end{abstract}

Keywords: Social Security, Progressivity, Lifetime Earnings, Mortality

\section{INTRODUCTION}

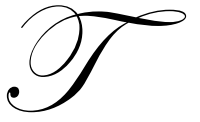

he Social Security system in its present form is facing significant financial challenges. Experts may disagree on exactly when the system will be unable to meet its obligations, but they all agree the time is coming. There is much less agreement on what should be done to preserve the system, or even if the system should be preserved. One important aspect of the debate is how to maintain universal or near-universal participation while still being fair. For example, opponents of means testing to receive Social Security benefits fear that eliminating benefits for some will change the system from social insurance to welfare, in perception if not in reality, and cause public support for the program to diminish. ${ }^{1}$

Central to the fairness issue is whether the system should be progressive; that is, should lower-income workers receive higher benefits, relative to the taxes they have paid, than higher-income workers? The principal argument against progressivity is that it requires a redistribution of income from those with higher lifetime earnings to those with lower lifetime earnings, a result that is viewed by some as being unfair to those individuals with higher earnings. Others argue that the Social Security system should emphasize social adequacy (i.e., the need for all workers to receive benefits that provide a certain standard of living) over individual equity, a result that requires progressivity in the system. ${ }^{2}$ Reasonable arguments can be made on either side of this issue, but it begs the following two questions: (1) is the current Social Security system progressive?; and (2) in making reforms to Social Security, should consideration be given to their potential impact on the progressivity of the system?

The current Social Security system is regressive with respect to taxes and progressive with respect to benefits. On the tax side, there is a limit on the amount of earnings subject to taxation for a given year (the "contribution base"). As a result, the taxes paid by individuals making more than the contribution base are lower, as 
a percentage of their total income, than those paid by individuals who make less than that amount. This outcome defines a regressive tax structure. However, the same annual limit also applies when those earnings are used in a benefit computation which, together with a progressive benefit formula, results in greater benefits (relative to the taxes paid) for individuals with lower incomes. This outcome defines a progressive benefit structure. So, when both taxes and benefits are considered, is the system as a whole regressive or progressive? This issue was addressed in a 2006 brief prepared by the Congressional Budget Office (CBO), which states: "For people with lower than average earnings, the ratio of the lifetime benefits they receive from Social Security to the lifetime payroll taxes they pay for the program is higher than it is for people with higher average earnings. In that sense, the Social Security system is progressive. For people in the bottom fifth of the earnings distribution, the ratio of benefits to taxes is almost three times as high as it is for those in the top fifth." ${ }^{3}$ However, as discussed below, there is conflicting evidence with regard to this question.

Proposals for reforming Social Security are often influenced by perceptions regarding the progressivity or regressivity of the current system. For example, politicians often limit their attention to the tax side of the system and, after concluding that Social Security is regressive, propose an increase in or elimination of the limit on the contribution base. ${ }^{4}$ This change would not affect the taxes paid by lower-income workers (i.e., those with earnings below the current limit), but it would increase the taxes paid by higher-income workers. The net effect is to increase the overall progressivity of the system, since benefits for higher-income workers would be even lower relative to their contributions. Another suggested reform is to implement a "means test" that would reduce or eliminate benefits paid to higher-income workers while not affecting those paid to lower-income workers. Even if benefit reductions for all workers were implemented, it is likely that the reductions would be proportionally greater for higher-income workers than for lower-income workers. In either case, the effect once again is to increase the overall progressivity of the system.

In assessing the progressivity of the system and the impact of various proposals, an alternative to focusing on current income (which can vary significantly from year to year) is to focus on lifetime earnings. The CBO noted that the "progressivity in the benefit formula is only partly offset by the fact that higher-earning individuals tend to live longer and thus collect benefits longer." (CBO, 2006) Recent studies, such as Cristia (2007), Duggan et al. (2007), and Waldron (2007), have shown a strong correlation between lifetime earnings and mortality, suggesting that the difference in life expectancy between lower-earning and higher-earning individuals may be getting larger. The result of this widening disparity is an erosion of the progressivity of the system, which may be viewed as desirable by some and undesirable by others. But, it does suggest that some level of tax increases or benefit reductions aimed at higher-income workers could be implemented while maintaining, but not increasing, the current level of progressivity in the system.

The purpose of the present study is to illustrate the impact of lifetime earnings and mortality on the progressivity of the retirement portion of the current Social Security system, and to estimate the degree to which benefits could be reduced while maintaining the system's progressivity if mortality differences are indeed increasing. Our results show that for a mortality difference of one or two years, benefit reductions in the range of $2.5 \%$ to $16 \%$ would be needed for a male living to age 80 . If the mortality difference grows to four or five years, the benefit reductions could be much greater (anywhere from approximately $14 \%$ to $31 \%$ ).

\section{BACKGROUND}

Is Social Security progressive or regressive? The answer to this question depends on how the variables are measured. The tax side of Social Security is clearly regressive; however, the benefit side is progressive in the sense that it replaces a higher percentage of past earnings for those with low earnings than it does for those with high earnings. Fullerton and Mast (2005) review several studies that show that, overall, the Social Security system is not very progressive and might even be regressive. In contrast, the Congressional Budget Office (2006) concludes the system is progressive. These different conclusions arise from differences in how progressivity, income, mortality, and other crucial variables are defined and measured. 
Fullerton and Mast (2005, p. 66) summarize their results as follows:

Clearly, the many assumptions and measurement decisions about individuals and data that are necessary to analyze the redistribution from Social Security can affect the outcome. To summarize, the following choices all cause Social Security to appear less progressive than otherwise:

1. Mortality estimates differentiated by income or education, rather than uniform.

2. Lifetime income, rather than annual income.

3. Total earnings, rather than those below the earnings cap.

4. $\quad$ Potential income, rather than actual income.

5. Household income, rather than individual income.

6. Higher discount rates, rather than lower ones.

Their number one item is differential mortality. Recent studies have concluded that individuals with higher lifetime earnings live longer, and that the gap between those with higher incomes and those with lower incomes is widening. Dr. Peter Orszag put it this way: "Some people know that better-educated, higher-income people live longer than less-educated lower-income people. Few people know that the gap between higher-income people and lower-income people has literally exploded." (Baicker, et al., 2008)

Empirical studies seem to support Dr. Orszag's assertion. Duggan et al. (2007) examined all retired-worker beneficiary records with birth years 1900 to 1942 who claimed benefits at age 62 or later. They concluded that differences in age of death between low and high lifetime income are on the order of two to three years. Cristia (2007), using Social Security Administration records on earnings, beneficiary, and mortality from the 1984, 1993, 1996, and 2001 panels of the Survey of Income and Program Participation concludes that "with respect to trends in differential mortality by lifetime earnings, there is substantive evidence pointing toward an increase in differential mortality in the period 1983 to 2003." Waldron (2007, p. 2), examining male birth cohorts spanning the years 1912 - 1941 (or deaths spanning the years $1972-2001$ at ages $60-89$ ), concludes that:

...the top half of the average relative earnings distribution has experienced faster mortality improvement than has the bottom half. Specifically, male Social Security-covered workers born in 1941 who had average relative earnings in the top half of the earnings distribution and who lived to age 60 would be expected to live 5.8 more years than their counterparts in the bottom half. In contrast, among male Social Security-covered workers born in 1912 who survived to age 60, those in the top half of the earnings distribution would be expected to live only 1.2 years more than those in the bottom half.

Regardless of the exact mortality difference, all of the research suggests that if differential mortality by lifetime earnings continues to increase, then the system will become less progressive. It is time to consider these differences when evaluating the current system or changes to it. ${ }^{5}$ The present study examines the impact of differential income-based mortality and estimates the reduction in benefits that will maintain the system's current level of progressivity.

\section{METHODOLOGY}

Tax and benefit calculations are made for workers beginning work in 1963 and retiring either: (1) early at age 62 (12/31/2003); (2) at normal retirement age of 65 (12/31/2006); or (3) past the normal retirement age at age 70 $(12 / 31 / 2011)$. Historical values are used for the contribution and benefit base, as well as for the social security (OASDI) tax rates. Taxes are estimated as the lesser of: (1) the OASDI Tax Rate times Worker Annual Income; or (2) the OASDI Tax Rate times the Contribution and Benefit Base. Benefit amounts are estimated using the Social Security benefit calculator. ${ }^{6}$ Five income levels are used: minimum wage, $25 \%$ of the social security wage base, $50 \%$ of the wage base, $75 \%$ of the wage base, and $100 \%$ of the wage base.

The resulting series of cash flows, negative for taxes and positive for benefits, are used to calculate an individual's net tax rate and ultimate internal rate of return from contributions to the retirement portion of social security. ${ }^{7}$ Calculations are made assuming the individual lives to age $70,75,80$, or 85 . The net tax rate is equal to 
the net benefit at retirement age (present value at retirement age of future benefits minus the future value at retirement age of all taxes paid) divided by the future value at retirement age of lifetime earnings. The discount rate used is $2 \%$. The internal rate of return is estimated based on annual cash flows, assuming all taxes are paid at the end of each year and that all benefits are received at the end of each year. Annual benefits are estimated as the monthly benefit from the social security benefit calculator times twelve. These results illustrate the degree of progressivity in the current system. Finally, the impact of differential mortality is examined by calculating the new benefit amounts for high-income individuals (100\% of wage base) that would be necessary to maintain the current level of progressivity in the system. This is accomplished by keeping their internal rate of return at the current level but assuming they live longer. Amounts are calculated for differential mortality of 1 to 5 years.

\section{RESULTS}

The monthly retirement benefits calculated for individuals beginning work on January 1, 1963 and retiring on December 31, 2003, 2006, or 2011 are shown in Table 1.

\begin{tabular}{|l|c|c|c|c|c|}
\hline \multicolumn{7}{|c|}{ Table 1: Social Security Monthly Retirement Benefits } \\
by Wage Class \\
\hline & Minimum Wage & $25 \%$ of Wage Base & $50 \%$ of Wage Base & $75 \%$ of Wage Base & $100 \%$ of Wage Base \\
\hline Retire at age 62 & $\$ 560$ & $\$ 639$ & $\$ 1,011$ & $\$ 1,282$ & $\$ 1,451$ \\
\hline Retire at age 65 & $\$ 742$ & $\$ 895$ & $\$ 1,422$ & $\$ 1,783$ & $\$ 2,007$ \\
\hline Retire at age 70 & $\$ 1,047$ & $\$ 1,340$ & $\$ 2,157$ & $\$ 2,627$ & $\$ 2,937$ \\
\hline
\end{tabular}

Tables 2, 3, and 4 show net tax rates for individuals based on their lifetime income and number of years receiving benefits after retirement. Workers with lower lifetime incomes pay lower tax rates, indicative of an overall progressive system.

\begin{tabular}{|c|c|c|c|c|c|}
\hline \multicolumn{7}{|c|}{$\begin{array}{c}\text { Table 2: Net Tax Rates by Wage Class } \\
\text { (Workers Retiring at Age 62) }\end{array}$} \\
\hline Live to: & Minimum Wage & $25 \%$ of Wage Base & $50 \%$ of Wage Base & $75 \%$ of Wage Base & $100 \%$ of Wage Base \\
\hline Age 70 & $-2.79 \%$ & $-0.15 \%$ & $2.29 \%$ & $3.73 \%$ & $4.91 \%$ \\
\hline Age 75 & $-10.37 \%$ & $-6.57 \%$ & $-2.79 \%$ & $-0.57 \%$ & $1.26 \%$ \\
\hline Age 80 & $-17.23 \%$ & $-12.39 \%$ & $-7.39 \%$ & $-4.46 \%$ & $-2.04 \%$ \\
\hline Age 85 & $-23.44 \%$ & $-17.66 \%$ & $-11.56 \%$ & $-7.98 \%$ & $-5.03 \%$ \\
\hline
\end{tabular}

\begin{tabular}{|c|c|c|c|c|c|}
\hline \multicolumn{7}{|c|}{$\begin{array}{c}\text { Table 3: Net Tax Rates by Wage Class } \\
\text { (Workers Retiring at Age 65) }\end{array}$} \\
\hline Live to: & Minimum Wage & $25 \%$ of Wage Base & $50 \%$ of Wage Base & $75 \%$ of Wage Base & $100 \%$ of Wage Base \\
\hline Age 70 & $0.88 \%$ & $2.91 \%$ & $4.70 \%$ & $5.84 \%$ & $6.75 \%$ \\
\hline Age 75 & $-8.39 \%$ & $-5.01 \%$ & $-1.59 \%$ & $0.59 \%$ & $2.31 \%$ \\
\hline Age 80 & $-16.78 \%$ & $-12.18 \%$ & $-7.28 \%$ & $-4.18 \%$ & $-1.71 \%$ \\
\hline Age 85 & $-24.38 \%$ & $-18.68 \%$ & $-12.44 \%$ & $-8.49 \%$ & $-5.35 \%$ \\
\hline
\end{tabular}

\begin{tabular}{|c|c|c|c|c|c|}
\hline \multicolumn{7}{|c|}{$\begin{array}{c}\text { Table 4: Net Tax Rates by Wage Class } \\
\text { (Workers Retiring at Age 70) }\end{array}$} \\
\hline Live to: & Minimum Wage & $25 \%$ of Wage Base & $50 \%$ of Wage Base & $75 \%$ of Wage Base & $100 \%$ of Wage Base \\
\hline Age 70 & n/a & n/a & n/a & n/a & n/a \\
\hline Age 75 & $-0.26 \%$ & $1.88 \%$ & $3.81 \%$ & $5.31 \%$ & $6.35 \%$ \\
\hline Age 80 & $-10.70 \%$ & $-7.08 \%$ & $-3.40 \%$ & $-0.55 \%$ & $1.44 \%$ \\
\hline Age 85 & $-20.16 \%$ & $-15.19 \%$ & $-9.93 \%$ & $-5.85 \%$ & $-3.00 \%$ \\
\hline
\end{tabular}


Tables 5, 6, and 7 show internal rates of return for individuals based on their lifetime income and number of years receiving benefits after retirement. Workers with lower lifetime incomes have higher internal rates of return, indicative of an overall progressive system.

\begin{tabular}{|c|c|c|c|c|c|}
\hline \multicolumn{7}{|c|}{$\begin{array}{c}\text { Table 5: Internal Rates of Return by Wage Class } \\
\text { (Workers Retiring at Age 62) }\end{array}$} \\
\hline Live to: & Minimum Wage & $25 \%$ of Wage Base & $50 \%$ of Wage Base & $75 \%$ of Wage Base & $100 \%$ of Wage Base \\
\hline Age 70 & $3.11 \%$ & $2.08 \%$ & $0.63 \%$ & $-0.45 \%$ & $-1.54 \%$ \\
\hline Age 75 & $4.85 \%$ & $4.31 \%$ & $3.12 \%$ & $2.25 \%$ & $1.38 \%$ \\
\hline Age 80 & $5.69 \%$ & $5.34 \%$ & $4.29 \%$ & $3.53 \%$ & $2.77 \%$ \\
\hline Age 85 & $6.16 \%$ & $5.91 \%$ & $4.94 \%$ & $4.24 \%$ & $3.55 \%$ \\
\hline
\end{tabular}

\begin{tabular}{|c|c|c|c|c|c|}
\hline \multicolumn{7}{|c|}{$\begin{array}{c}\text { Table 6: Internal Rates of Return by Wage Class } \\
\text { (Workers Retiring at Age 65) }\end{array}$} \\
\hline Live to: & Minimum Wage & $25 \%$ of Wage Base & $50 \%$ of Wage Base & $75 \%$ of Wage Base & $100 \%$ of Wage Base \\
\hline Age 70 & $1.58 \%$ & $0.17 \%$ & $-1.42 \%$ & $-2.75 \%$ & $-4.07 \%$ \\
\hline Age 75 & $4.40 \%$ & $3.85 \%$ & $2.67 \%$ & $1.72 \%$ & $0.79 \%$ \\
\hline Age 80 & $5.54 \%$ & $5.27 \%$ & $4.25 \%$ & $3.44 \%$ & $2.65 \%$ \\
\hline Age 85 & $6.13 \%$ & $5.98 \%$ & $5.05 \%$ & $4.32 \%$ & $3.61 \%$ \\
\hline
\end{tabular}

\begin{tabular}{|c|c|c|c|c|c|}
\hline \multicolumn{7}{|c|}{ Table 7: Internal Rates of Return by Wage Class } \\
(Workers Retiring at Age 70) \\
\hline Live to: & Minimum Wage & $25 \%$ of Wage Base & $50 \%$ of Wage Base & $75 \%$ of Wage Base & $100 \%$ of Wage Base \\
\hline Age 70 & n/a & n/a & n/a & n/a & n/a \\
\hline Age 75 & $2.10 \%$ & $1.03 \%$ & $-0.26 \%$ & $-1.58 \%$ & $-2.76 \%$ \\
\hline Age 80 & $4.56 \%$ & $4.17 \%$ & $3.19 \%$ & $2.22 \%$ & $1.36 \%$ \\
\hline Age 85 & $5.56 \%$ & $5.40 \%$ & $4.55 \%$ & $3.70 \%$ & $2.97 \%$ \\
\hline
\end{tabular}

Reduced benefit amounts necessary to maintain current internal rates of return for individuals making $100 \%$ of the wage base are shown in Tables 8, 9, and 10. Differential mortality of one year to five years is shown. ${ }^{8}$

\begin{tabular}{|c|c|c|c|c|c|}
\hline \multicolumn{6}{|c|}{$\begin{array}{l}\text { Table 8: Reduced Monthly Benefit Amounts to Maintain Current Internal Rates } \\
\text { of Return for Individuals Earning } 100 \% \text { of the Wage Base } \\
\text { (Workers Retiring at Age 62) }\end{array}$} \\
\hline \multicolumn{6}{|c|}{ Differential Mortality of: } \\
\hline Live to: & 5 Years & 4 Years & 3 Years & 2 Years & 1 Year \\
\hline Age 70 & $\$ 858$ & $\$ 938$ & $\$ 1,031$ & $\$ 1,143$ & $\$ 1,279$ \\
\hline Age 75 & $\$ 1,083$ & $\$ 1,138$ & $\$ 1,203$ & $\$ 1,273$ & $\$ 1,356$ \\
\hline Age 80 & $\$ 1,208$ & $\$ 1,250$ & $\$ 1,292$ & $\$ 1,342$ & $\$ 1,393$ \\
\hline Age 85 & $\$ 1,285$ & $\$ 1,313$ & $\$ 1,344$ & $\$ 1,377$ & $\$ 1,413$ \\
\hline \multicolumn{6}{|c|}{ Percentage Decrease From Current Benefit Amount of $\$ 1,451$ per Month } \\
\hline Age 70 & $40.85 \%$ & $35.39 \%$ & $28.93 \%$ & $21.20 \%$ & $11.84 \%$ \\
\hline Age 75 & $25.34 \%$ & $21.61 \%$ & $17.13 \%$ & $12.27 \%$ & $6.53 \%$ \\
\hline Age 80 & $16.72 \%$ & $13.85 \%$ & $10.98 \%$ & $7.53 \%$ & $3.97 \%$ \\
\hline Age 85 & $11.41 \%$ & $9.55 \%$ & $7.39 \%$ & $5.09 \%$ & $2.65 \%$ \\
\hline
\end{tabular}




\begin{tabular}{|c|c|c|c|c|c|}
\hline \multicolumn{6}{|c|}{$\begin{array}{l}\text { Table 9: Reduced Monthly Benefit Amounts to Maintain Current Internal Rates } \\
\text { of Return for Individuals Earning 100\% of the Wage Base } \\
\text { (Workers Retiring at Age 65) }\end{array}$} \\
\hline \multicolumn{6}{|c|}{ Differential Mortality of: } \\
\hline Live to: & 5 Years & 4 Years & 3 Years & 2 Years & 1 Year \\
\hline Age 70 & $\$ 900$ & $\$ 1,022$ & $\$ 1,175$ & $\$ 1,373$ & $\$ 1,638$ \\
\hline Age 75 & $\$ 1,363$ & $\$ 1,456$ & $\$ 1,563$ & $\$ 1,685$ & $\$ 1,831$ \\
\hline Age 80 & $\$ 1,600$ & $\$ 1,665$ & $\$ 1,733$ & $\$ 1,817$ & $\$ 1,904$ \\
\hline Age 85 & $\$ 1,733$ & $\$ 1,779$ & $\$ 1,825$ & $\$ 1,879$ & $\$ 1,942$ \\
\hline \multicolumn{6}{|c|}{ Percentage Decrease From Current Benefit Amount of $\$ 2,007$ per Month } \\
\hline Age 70 & $55.16 \%$ & $49.08 \%$ & $41.45 \%$ & $31.59 \%$ & $18.39 \%$ \\
\hline Age 75 & $32.11 \%$ & $27.44 \%$ & $22.15 \%$ & $16.02 \%$ & $8.76 \%$ \\
\hline Age 80 & $20.28 \%$ & $17.06 \%$ & $13.64 \%$ & $9.48 \%$ & $5.12 \%$ \\
\hline Age 85 & $13.64 \%$ & $11.35 \%$ & $9.07 \%$ & $6.37 \%$ & $3.26 \%$ \\
\hline
\end{tabular}

\begin{tabular}{|c|c|c|c|c|c|}
\hline \multicolumn{6}{|c|}{$\begin{array}{l}\text { Table 10: Reduced Monthly Benefit Amounts to Maintain Current Internal Rates of Return } \\
\text { for Individuals Earning } 100 \% \text { of the Wage Base } \\
\text { (Workers Retiring at Age 70) }\end{array}$} \\
\hline & \multicolumn{5}{|c|}{ Differential Mortality of: } \\
\hline Live to: & 5 Years & 4 Years & 3 Years & 2 Years & 1 Year \\
\hline Age 70 & $\mathrm{n} / \mathrm{a}$ & $\mathrm{n} / \mathrm{a}$ & $\mathrm{n} / \mathrm{a}$ & $\mathrm{n} / \mathrm{a}$ & $\mathrm{n} / \mathrm{a}$ \\
\hline Age 75 & $\$ 1,367$ & $\$ 1,542$ & $\$ 1,758$ & $\$ 2,040$ & $\$ 2,415$ \\
\hline Age 80 & $\$ 2,022$ & $\$ 2,152$ & $\$ 2,306$ & $\$ 2,479$ & $\$ 2,688$ \\
\hline Age 85 & $\$ 2,354$ & $\$ 2,446$ & $\$ 2,455$ & $\$ 2,658$ & $\$ 2,788$ \\
\hline \multicolumn{6}{|c|}{ Percentage Decrease From Current Benefit Amount of \$2,937 per Month } \\
\hline Age 70 & $\mathrm{n} / \mathrm{a}$ & $\mathrm{n} / \mathrm{a}$ & $\mathrm{n} / \mathrm{a}$ & $\mathrm{n} / \mathrm{a}$ & $\mathrm{n} / \mathrm{a}$ \\
\hline Age 75 & $53.47 \%$ & $47.51 \%$ & $40.13 \%$ & $30.56 \%$ & $17.79 \%$ \\
\hline Age 80 & $31.17 \%$ & $26.73 \%$ & $21.49 \%$ & $15.59 \%$ & $8.50 \%$ \\
\hline Age 85 & $19.84 \%$ & $16.72 \%$ & $13.38 \%$ & $9.49 \%$ & $5.09 \%$ \\
\hline
\end{tabular}

Benefit decreases range from $2.65 \%$ for a worker retiring at age 62 and living to age 85 , to $55.16 \%$ for a worker retiring at age 65 and living only to age 70 . The most representative cases are likely those with individuals who live to ages 80 or 85 , given that average life expectancy at age 65 was 18.7 years in $2005 .{ }^{9}$ For individuals living to age 80 or 85 , the required benefit reductions are in the range of $2.65 \%$ to $31.17 \%$ (see Charts 1 and 2 ).

\section{CONCLUSION}

Social Security reforms are necessary to maintain the long-run solvency of the system. Proposed reforms include increasing Social Security tax rates, increasing or eliminating the limit on the contribution base, and reducing benefits. Politicians, economists, and concerned citizens evaluate these proposals based not only on their financial efficacy, but also on their perceived fairness. These parties may have different views regarding the fairness of a progressive system. However, given the evidence of a significant and growing differential mortality based on lifetime earnings, a reduction in benefits based on lifetime earnings could improve the long-run viability of the system $^{10}$ while maintaining its current level of progressivity. 

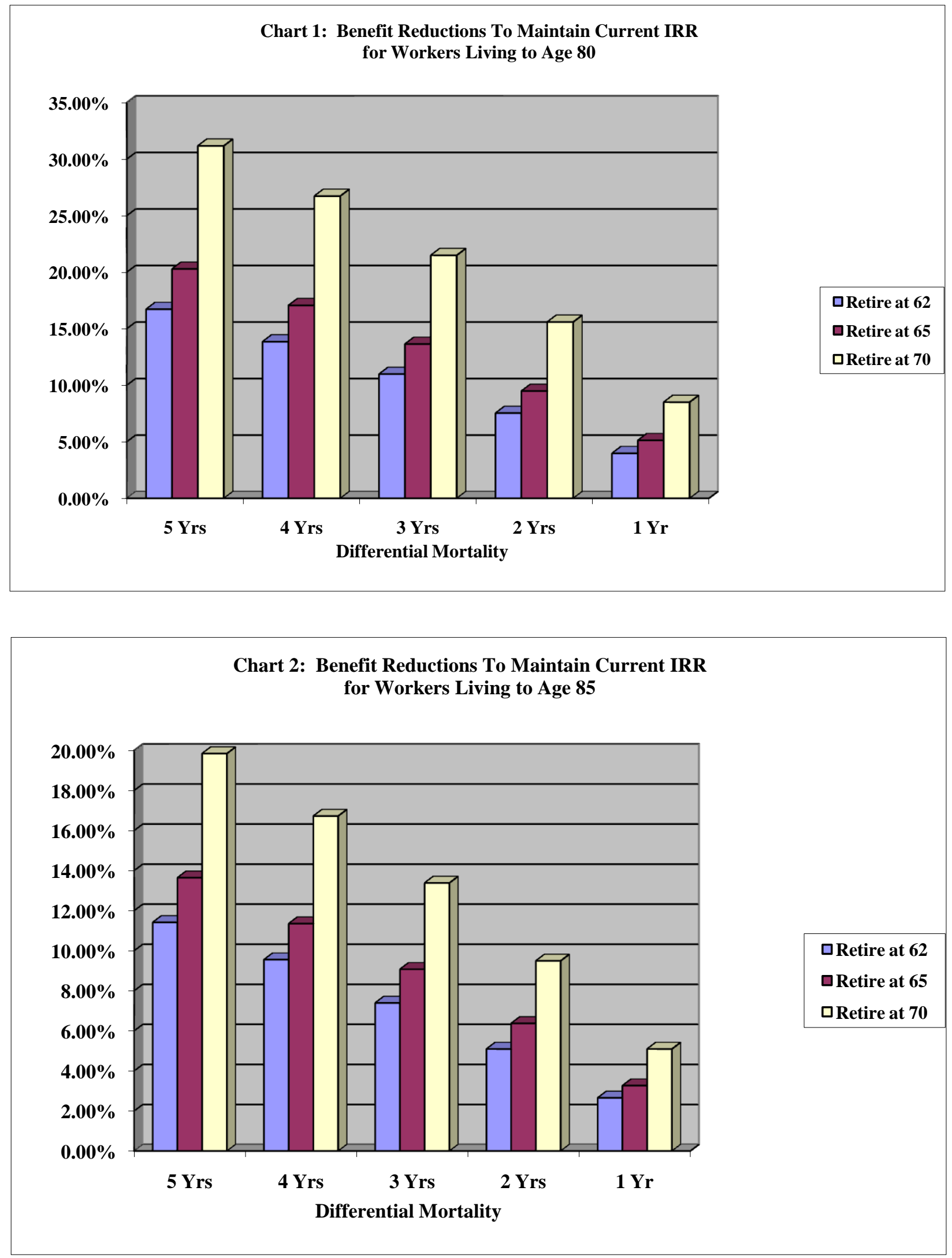


\section{AUTHOR INFORMATION}

Dr. Alan D. Eastman is a Professor of Finance. His academic background includes a bachelor's degree in Business Administration from Bucknell University, a master's degree in Accounting from the Pennsylvania State University, and a doctorate in Risk Management and Insurance from Florida State University. Dr. Eastman's business experience includes work in public accounting and small business management. Dr. Eastman joined IUP in 1997, and prior to that held a faculty position at Elon University. His teaching and research interests include Financial Management, Investments, Insurance and Insurance Regulation.

Dr. Kevin L. Eastman is a Professor of Finance. He earned a bachelor's and master's degree in Business Administration from Bucknell University, and a master's degree and doctorate in Managerial Science and Applied Economics (with a major in Risk and Insurance) from the Wharton School of Business at the University of Pennsylvania. Dr. Eastman joined Georgia Southern University in 2007, after spending eighteen years on the faculty at Florida State University and holding previous positions at East Carolina University, Elon University, and the Pennsylvania State University. His teaching and research interests include Financial Management, Enterprise Risk Management, Insurance Operations and Regulation, and Automobile Insurance Issues and No-Fault Systems.

\section{REFERENCES}

1. Baicker, Katherine, Jeffrey Brown, Douglas Holtz-Eakin, and Peter Orszag, Future of Social Security, Medicare, and Medicaid: Is U.S. Entitlement Spending Sustainable?, Risk Management \& Insurance Review, Volume 11, No. 1, pp. 1 -21, Spring 2008.

2. Congressional Budget Office, Is Social Security Progressive?, Economic and Budget Issue Brief, pp. $1-8$, December 15, 2006.

3. Cristia, Julian P, The Empirical Relationship Between Lifetime Earnings and Mortality, Congressional Budget Office Working Paper Series, 2007 - 11, August 2007.

4. Cushing, Matthew J., Net Marginal Social Security Tax Rates over the Life Cycle, National Tax Journal, Volume 58, Issue 2, pp. 227 - 245, June 2005.

5. Duggan, James E., Robert Gillingham, and John S. Greenlees, Mortality and Lifetime Income: Evidence from U.S. Social Security Records, International Monetary Fund Working Paper WP/07/15, January 2007.

6. Fullerton, Don and Brent D. Mast, Income Redistribution from Social Security, American Enterprise Institute, Washington, D.C., 2005.

7. Milligan, Susan, Obama Proposes Increasing Social Security Tax on Wealthy, Boston Globe, October 28, 2007.

8. Natarag, Sita, and John B. Shoven, Comparing the Risks of Social Security With and Without Individual Accounts, The American Economic Review, Vol. 93, No. 2, May 2003.

9. Rejda, George, Social Insurance and Economic Security (4th Edition), Prentice Hall, 1991.

10. Social Security Advisory Board, Social Security: Why Action Should Be Taken Soon, July 2001.

11. U.S. Department of Health and Human Services, Center for Disease Control and Prevention, National Center for Health Statistics, Health, United States, 2007, DHHS Publication No. 2007-1232, November 2007.

12. Waldron, Hilary, Trends in Mortality Differentials and Life Expectancy for Male Social Security-Covered Workers, by Socioeconomic Status, Social Security Bulletin, Vol. 67, No. 3, 2007.

13. Wheeler, Tim, Bush 'Means Test' Would Wreck Social Security, People's Weekly World Newspaper, May 7, 2005.

\section{ENDNOTES}

\footnotetext{
${ }^{1}$ For example, see Wheeler (2005).

${ }^{2}$ For a discussion of these issues, see Rejda (1991).

${ }^{3}$ CBO, "Is Social Security Progressive?" Economic and Budget Issue Brief, December 15, 2006.

${ }^{4}$ During the 2008 presidential campaign, Democratic nominee Barrack Obama proposed raising social security taxes on the wealthy, saying "the nations' 'most regressive tax' needed to be revamped to increase revenues to the retirement fund and spread the burden of paying for the program more evenly." Milligan, Susan. Boston Globe, Oct. 28, 2007.
} 


\footnotetext{
${ }^{5}$ Duggan, et al. (2007) state, "The income-related differences in life expectancy are substantial enough to require consideration when evaluating the distributional consequences of proposals to modify various features of the Social Security program or when evaluating the existing program."

${ }^{6}$ The Social Security benefit calculator is available at http://www.ssa.gov. The wage and benefit base and the OASDI tax rate are estimated to remain constant at 2006 levels for all future years.

${ }^{7}$ See Cushing (2005) for similar use of net tax rates and Nataraj and Shoven (0203) for analysis using internal rates of return.

${ }^{8}$ Similar results are found for workers making $75 \%$ or $50 \%$ of the wage base.

${ }^{9}$ U.S. Department of Health and Human Services, Center for Disease Control and Prevention, National Center for Health Statistics. Health, United States, 2007, DHHS Publication No. 2007-1232, November 2007.

${ }^{10}$ The Social Security Advisory Board, in its July 2001 report "Social Security: Why Action Should Be Taken Soon.," evaluated various proposals to address long-run solvency problems. One proposal involved gradually reducing benefit formula factors for middle and upper income workers from $90 \%$ of the first $\$ 561$ of average monthly earnings, 32\% of the amount above $\$ 561$ through $\$ 3,381$, and $15 \%$ of additional covered earnings, to $90 \%$ of the first $\$ 561$ of average monthly earnings, $21 \%$ of the amount above $\$ 561$ through $\$ 3,381$, and $10 \%$ of additional covered earnings. This change was expected to resolve $87 \%$ of the projected Social Security deficit. The impact of the change is approximately a $25 \%$ reduction in benefits for workers at the current maximum wage and benefit base.
} 


\section{NOTES}

